"I do too," said Finn. "Honestly. It's the most wonderful thing I've ever seen."

"Really?" Gala beamed at him.

"Really, truly."

They put the marbles into the other two chimneys. It seemed that each chimney led to a slightly different route. This time a tiny cat chased an almost invisible mouse, a dragon popped its head out of its lair and a woman pulled a bucket from a well. Then the hens bent to peck again, and as they did so there was a click. Slowly, creakily, the roundalay divided in half and the two halves swung apart, like a book opening. They gasped. Like magic, the secret insides of the town were revealed. There was a man in his bath-tub, a family sitting round a table, a choir singing in church, a cow suckling a calf in a cow-shed. A man had his arms round piles of gold, the baker was taking bread from the oven, two women were bent over a clothes-trough, and soldiers were lolling around the inn, drunk.

Finn and Gala couldn't take it all in. There was a girl curled up, lonely, in an attic room, a monk writing a manuscript, a band playing for a dance in an elegant, circular ballroom. And then, hanging down from the ballroom ceiling over the dancers, Finn saw the crown...

\title{
Reviews $\mathcal{E}$ previews
}

(10 BOOK REVIEW

\section{Swedes and Finns in the history of New Zealand immigration}

From the Midnight Sun to the Long White Cloud. Finns in New Zealand.

Olavi Koivukangas. Turku: Institute of Migration, 1996. 397 pp, illus.

\section{Reviewed by Rolf W. Brednich}

In the current debate about problems of contemporary immigration it seems helpful to consider that New Zealand has always been a target for non-British settlers from overseas, especially from Europe. Some of the different European groups of immigrants who arrived during the 19 th and 20th centuries have already been the subject of a series of scholarly studies. We could mention works on German (Bade 1993), Italian (Ballara 1975), Yugoslav (Trlin 1979), Polish (Pobog-Jaworowski 1990), Scandinavian (Aminoff 1988, Bender/Larsen 1990), and Swiss (Weber de Candolle 1967) immigrants. ${ }^{1}$

These publications have recently been augmented by a new work by Olavi Koivukangas, director of the Turkubased Institute of Migration. Koivukangas has already contributed three books to the study of Scandinavians and Finns in Australia. ${ }^{2}$ In 1991 the Academy of Finland granted him a fellowship to study Finns in New Zealand, which enabled him to spend some months as visiting fellow at Massey University. There he was supported by Andrew D. Trlin, a specialist in South European immigration to New Zealand.

New Zealand's Finnish minority does not form a particularly prominent nor outstanding group of immigrants. One could even ask 'Are there any Finns in New Zealand?', a question to which the author of this book would

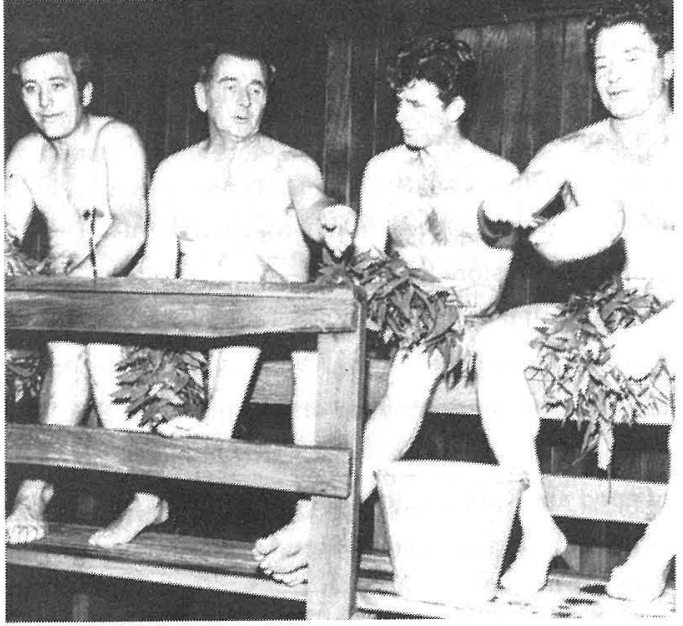

answer 'You can hardly find a place on earth where there aren't any Finns!' - a stereotype which could be applied as well to Dutch, Germans, Italians, Scotsmen or Irishmen. But, indeed, there are quite a number of Finlanders who have chosen New Zealand as their destination. With great care and devotion, the author has investigated their times and lives. Most of them will find their names and family records printed in the current book, and some lucky ones even additional family photographs and other facsimile documents. The photographs are evidence of the author's thorough research, and positioned well in the text. Special care is taken with well formulated captions. Most of the photographs are attributed to the Institute of Migration in Turku, but unfortunately not to their original sources in New Zealand. The comprehensive Name Index of Finnish immigrants to New Zealand before and after 1949 (pp. 299-397) will be a boon to genealogists. Our task is to concentrate on the results of the present study for emigration research in general.

Above: The Finnish Sauna in New Zealand is a symbol of Finnish origin and lifestyle (Kawerau, ca.1960). Photograph: From the Midnight Sun (1996). 
Finland is a bilingual country with a Swedish minority of six percent. Swedes in Finland continue to identify as Swedes. Swedish settlement in Finland dates back to the 16th century, and is concentrated along the coastline, while Finns continued to occupy the hinterland.

Finland has for a long time been a country of heavy emigration. In the first half of the last century some 200,000 people moved to Russia; in the second half of the century over 300,000 went to North America; after World War II about the same number left for Sweden. All in all, not more than approximately 2,000 Finlanders ended up on the remote shores of New Zealand, a comparatively small number. The aim of Koivukanga's study is to 'provide as comprehensive an account as possible of the Finns in New Zealand from the first visit of a Finn to the present time and to evaluate the Finnish contribution to the development of New Zealand' (p21). The research methods employed for this study are those of historical demography and social history; they include archival investigation and fieldwork in the North and South Islands.

The first Finlander to step ashore in New Zealand was Herman Dietrich Spöring (ca.1733-1770) from Turku (Åbo), whose strong interest in natural science brought him into contact with the Swedish botanist Carl Solander, and eventually with James Cook who took him on his first voyage round the world (New Zealand 1769/70). Spöring served Cook as a draughtsman and contributed invaluable sketches of New Zealand coast lines and of Māori art. He did not see Europe again but died on the way back across the Indian Ocean. The next visitors to the New Zealand coasts were some Finnish whalers whose traces in South Island outposts are not very evident. The same is true for the Finnish participation in the South Island gold rushes of the 1860s which can only be described with terms like 'estimated', 'possibly', 'obviously', 'could have been', 'presumably' (p46). More obvious is the early Finnish influx to the settlements of Banks Peninsula. Many a Finnish sailor jumped off his ship at Port Lyttelton and started a new career as wharf labourer, farm labourer, or carpenter. These were followed by other settlers of Finnish origin who made their homes in scattered places of the South Island and found a living in road building, trading, milling and sheep farming.

There is one interesting point about all these 'Finnish' settlers of the 19th century: as a matter of fact, none of them bears any Finnish names. Beginning with Herman Spöring, we instead find all kinds of Swedish family names: the Andersons, Haggmans, Isaacsons, Nyströms, the Wests and Asplunds are not Finns in the strict sense of the word. They were born in what is now Finland, but belonged to the Swedish population which settled on the southern and western coasts of Finland. Many of them were seamen. That it was the Swedes of Finland, rather than Finns who immigrated to New Zealand during the 19 th century, can be credited to the coastal, seafaring characteristics of the Swedes. Not just for the sake of our contemporary understanding of political correctness but also for ethnographic and scholarly accuracy, it is not justified to call these immigrants of Swedish origin 'Finns'. They are at least Swedish-Finns or Swedish-speaking Finns. If a Russian scholar were to write an emigration history of his country he could, by the same right, include these Swedes from Finland in his account, because until 1917 Finland belonged to the Russian empire and they were Russian subjects. Admittedly, Koivukangas could not have asked these first settlers about their identity, but he could have done more about this issue in his book. He never explains, for instance, which language the early settlers used to communicate with each other. What was the language of the old family bible (p55)? Why did Andrew Erikson love to tell stories about his favourite warrior Gustav Adolf of Sweden? Which language was an interpreter needed for in the trial of Nils Jacobson who murdered Max Johnson (p65-6)? Why was this case reported in the Swedish newspaper Österbottniska Posten (p271)? Which language was used in the emigrant letters of John Henry Sandos (p75)? Which 'language of the old country' was spoken in the house of Anders Wilhelm Erikson in Christchurch (p79)? You have to read between the lines, keeping in mind that these new South Islanders of the 19th century came from Munsala on the coast of Bothnia. And Bothnia, we learn at the end of the book, was a Swedish-speaking area of Finland (p246). There you also come across a map (p247) indicating that the majority of Finnish emigrants who left their country before 1949 came from the Swedish belt around the Eastern Sea. So it seems that the first half of this book, Chapters II - VIII, is not in accordance with its title.

Happily, the title fits the second half much better because the settlers whose fates are dealt with in chapters $X$ - XIV are real Finns with real Finnish family names like Hyvönen, Kiljunen, Myllärinen, and Reinikkala. They came to New Zealand in two waves in the 1950s on a government-assisted contract scheme, settling in Tokoroa and Kawerau and working in the pulp and paper mills, where they made a considerable contribution. Finnish Clubs were active in the two industrial centres until the mid 1980s. Lutheran churches and common sauna bathrooms are symbols of Finnish origin and heritage. The second generation of New Zealand Finns who have grown up here show less interest in maintaining their original cultural identity, and with the disappearance of the language, in the years to come, as the author puts it, there will be 'only memoirs, family traditions and histories of the Finnish contribution to the building of a modern industrial centre' (p200)

The book does not fully explore the reasons Swedish Finns in the 19th century and Finns in the 20th century left their country, how they got information about New Zealand, how long their ties with the old country lasted, 
and what happened to the relatively high percentage of people who returned to Finland at the end of their working contracts. Further, the author, director of a Finnish Institute of Migration, has concentrated his research totally on New Zealand. But why did Finlanders leave their country? The chance to comprehend migration as a problem which has to do with both countries - the one losing emigrants and the other one receiving them as immigrants - has eluded him. In this respect, the theoretical and methodological uses of this book are perhaps rather limited.

This is above all a sociable book. The regional histories, the place names, the family lives, the intermarriages, the famous New Zealanders, the social and community activities it describes and depicts will appeal to those who write New Zealand's history from the coal face - alone, the New Zealand Society of Genealogists has around 8,000 members.

\section{NOTES}

1 Bade, James N. (ed). The German Connection. New Zealand and German-speaking Europe in the nineteenth century. Auckland 1993. Ballara, Bruno. Presenza italiana in Nuova Zelanda. Auckland 1975.

Trlin, Andrew D. Now respected, once despised. Yugolavs in New Zealand. Palmerston North 1970.

Pobog-Jaworowski, Jerzy W. History of the Polish settlers in New Zealand 1876-1987. Warsaw 1990.

Aminoff, Sten. Sevenskarna i Nya Zeeland. Växjö 1988.

Bender, Henning; Larsen, Birgit. Danish emigration to New

Zealand. Aalborg 1990

Weber-de Candolle, Irene. The first Swiss in New Zealand. Wellington 1967.

2 Koivukangas, Olavi. Scandinavian immigration and settlement in Australia before World War II. Kokkola 1972.- Koivukangas, Olavi Martin, John S. The Scandinavians in Australia. Melbourne 1986. Koivukangas, Olavi. Sea, gold and sugarcane; Finns in Australia 18511947. Turku 1986

3 See the caption of the photograph on p109: "Britas pojkes pojke har kommithem" (Brita's grandson has come home) is partly Swedish.

\section{Response to Paul Morris}

\section{HAL LEVINE}

I feel that Paul Morris has produced a rather idiosyncratic critique of our book Far from the Promised Land? (see New Zealand Studies vol 6, no 1). On the opening page Ann Beaglehole and I announce that our research is about the experience of 'being Jewish in New Zealand', so when the reviewer demands a 'view of the community, qua community' he misrepresents our objective to readers. Our research group chose to interview a relatively small number of people from a wide variety of backgrounds, in depth, to gain an understanding of personal Jewish identity in New Zealand. Such a corpus of data is neither representative nor useful for any statistical or normative evaluation of 'the community'. It does instead show something of the diverse ways that Jewish people in this country explain their Jewishness.
Paul Morris argues that the authors subscribe to 'a somewhat extreme version of the constructivist view of identity' but there he is again muddling the difference between communal and individual representations of identity. Our data show that personal Jewish identity in New Zealand incorporates themes of

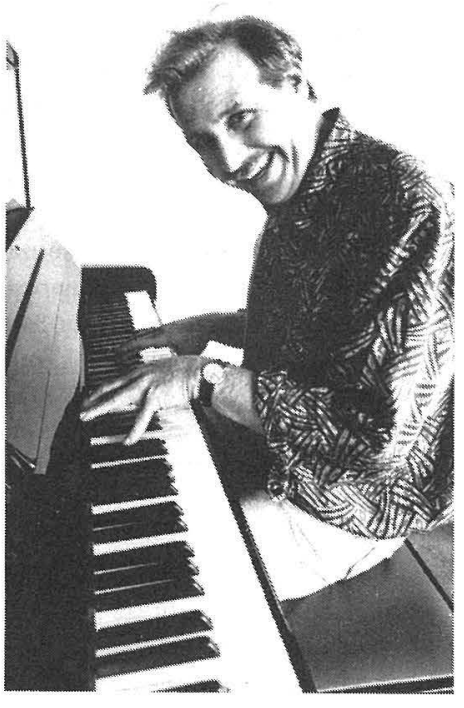
self-reflexive choice which are current in the country's culture. Of course 'the decision to recognise ... that one is a Jew' necessitates the notion that there is an existing community of Jews, but we live in a time and society where it is uniquely easy to make the decision to disassociate from the community or from being Jewish at all. No community of Jews or gentiles exists in New Zealand that can force us to be Jews if we don't want to, nor tell us that our particular views of Jewishness, as odd as they may be from an orthodox religious point of view, lack authenticity. Even our most orthodox respondents realised perfectly well that adhering to the laws and customs of the Jewish religion was a choice they made.

The reviewer's statement that Orthodox Jews constitute the 'single largest identifiable sector of the community' is disingenuous. We give figures in the book that show that most Jews who affiliate to congregations in New Zealand do join an Orthodox centre, but this hardly makes these people Orthodox Jews. I am myself a member of such a congregation, but my motivations and beliefs could not be termed orthodox or even religious. From the very small numbers attending services, from discussion with people at the centre, survey data, and our interviews, we concluded that the membership of orthodox congregations far exceeds the number of Orthodox Jews. Yes, lots of us come in for Yom Kippur. I think that Far from the Promised Land?, which could have been subtitled 'Representations of Symbolic Ethnicity', provides good answers to why we do.

Above: Far from the Promised Land? explores ways of being Jewish in New Zealand. Jonathan Besser, pianist and composer, was one of the book's participants. Photograph: Paul Thompson. 